DOI https://doi.org/10.30525/978-9934-26-000-1-27

\title{
РОЛЬ ІСТОРИКО-КУЛЬТУРНОГО КОНТЕНТУ УКРАЇНСЬКИХ ЗМІ У ФОРМУВАННІ НАЦІОНАЛЬНОЇ СВІДОМОСТІ (НА ПРИКЛАДІ ІНФОРМАЦЙНО-АНАЛІТИЧНОГО ТИЖНЕВИКА «ДЗЕРКАЛО ТИЖНЯ. УКРАЇНА»)
}

\author{
Мадей А. С. \\ асистент кафедри періодичної преси \\ Інститут журналістики Київського національного університету \\ імені Тараса Шевченка \\ м. Київ, Украӥна
}

«Дзеркало тижня. Україна» сміливо можна назвати демократичним суспільно-політичним виданням, що пробуджує опозиційні настрої та системно, програмно формує національну свідомість українців - на політичному, культурному та історичному рівнях. При чому за 26 років свого існування інформаційно-аналітичний тижневик жодного разу не ставав «пресою на замовлення», завжди мав авторитет справді якісної, незалежної преси, чим і здобув повагу та довіру багатьох тисяч освічених людей, інтелігенції України. Ще на початку свого життєвого шляху, коли коли вийшов сотий номер видання, редакція нагадала читачам свою принципову позицію: «Ми чітко усвідомлюємо: у справі розбудови незалежної України незалежна газета так само важлива, як і незалежний громадянин, незалежний власник, незалежна гривня. Оскільки залежне «Дзеркало» - це вже й не дзеркало зовсім, а так - «кімната сміху», в якій можна побачити своє «замовне» відображення: хочеш зменшене, хочеш - непомірно збільшене...» («ДТ» від 31.08.96) [2].

Тема дослідження набуває все більшої актуальності після подій Євромайдану. Історико-культурна проблематика у медіа набирає нових обрисів, тенденцій і перестає бути «декоративною ширмою», за якою відбувається переділ влади та ресурсів. ЗМІ все частіше подають питання історії та культури через призму політичного: хто відповідальний за руйнування пам'яток архітектури, за якими правилами функціонуватиме кіноіндустрія і книговидання, хто ці правила встановлює і лобіює, що це таке національний культурний продукт тощо. Тож необхідно на практичному і теоретико-методологічному рівнях дослідити нові підходи, принципи висвітлення у ЗМІ історичної та культурної проблематики, в тому числі й у контексті соціально-політичної ситуації.

Метою роботи $є$ дослідження ролі історико-культурного контенту українських медіа як формотворчого чиннику національної свідомості.

Для вивчення обрано інформаційно-аналітичний тижневик «Дзеркало тижня. Україна» за 2004-2014 рр. Такий вибір зумовлено необхід- 
ністю якомога повніше відобразити специфіку i зокрема динаміку подання 3МІ історико-культурної проблематики у контексті політичних i соціально-економічних перетворень. Саме на ці роки припадають, зокрема роки Помаранчевої революції, президентські вибори, події Євромайдану.

Новизна дослідження полягає в тому, що в роботі вперше виокремлено основні підходи, на основі яких реалізується місія історикокультурного контенту «Дзеркала тижня. України» як формотворчого чинника національної свідомості українців.

Історіографія питання дослідження історико-культурного контенту преси у контексті соціальних комунікацій перебуває на етапі формування. Внаслідок багаторічної «узурпації» вітчизняної науки радянською владою, партійною ідеологією окремі аспекти теми стали предметом уваги журналістикознавців, істориків, археологів, політологів та інших вчених лише $з$ другої половини 1990-их років. Тільки з проголошенням незалежності, прийняттям Конституції України, нові соціальні умови поставили якісно інші завдання перед українськими науковцями, у тому числі й щодо дослідження історико-культурного контенту ЗМІ.

Проблематика нашого дослідження $є$ складовою, відгалуженням журналістики як фаху, теоретичний фундамент якої заклали відомі вітчизняні науковці (Д. М. Прилюк, А. З. Москаленко). Сучасні українські фахівці із питань соціальних комунікацій (В. В. Різун, Т. О. Приступенко, В. Ф. Іванов та ін.) успішно продовжують розвивати напрямок масово-інформаційної діяльності, вивчення правових засад діяльності ЗМІ. На особливу увагу заслуговують дослідження жанрових форм у журналістиці (В. І. Шкляр, Ю. Ф. Ярмиш, В. Й. Здоровега тощо), а також праці, де вивчено вплив газетного тексту, його стилістичних особливостей (О. Д. Пономарів, Н. Ф. Непийвода, А. І. Мамалига та ін.) [3], [4], [5].

Автори матеріалів історико-культурної проблематики ніколи не ховалися від проблем, від часу і намагалися, звичайно, зі своїх об'єктивних позицій, говорити чесно - у будь-яких політичних, соціальноекономічних ситуаціях. Так, наприклад, після Помаранчевої революції, у часи президентства Віктора Ющенка (2005-2010 рр.) - публіцисти, коментатори «Дзеркала тижня. Україна» були досить відвертими, щирими, коли говорили про так звану «хуторянську культуру», «поплавщину» - констатували, що це підміна понять, яка шкодить справжній культурній парадигмі. У 2011-2013 рр., за президентства Віктора Януковича, тижневик «Дзеркало тижня. Україна» був одним із небагатьох видань в Україні - розумно-критичним, аргументованим, але ніколи не істеричним. Автори продовжували закликати, щоб влада, культура повернула очі від низькопробного кітчу, який став ще більш популярним за президентства Віктора Януковича. 3 початком подій Євромайдану, з кінця 2013 р., відділи «Культура» та «Архіваріус» «Дзеркала 
тижня. Україна» також не залишилися осторонь доленосних для українського народу подій. Тодішні публікації історико-культурної проблематики містили прозорі ідеї згуртування, єднання громадян. Зокрема місію лідерів думок, поводирів національних поглядів виконували на сторінках тижневика відомі постаті культури - артисти, співаки, письменники, музиканти тощо, які буквально жили із народом на Майдані.

Виокремимо основні підходи, на основі яких реалізується місія історико-культурного контенту «Дзеркала тижня. України» як формотворчого чинника національної свідомості українців:

1) Матеріали історичної та культурної тематики на сторінках видання основано на патріотичних підходах. Автори тижневика сповідують поважливе ставлення до національної історії, гордість за матеріальні та духовні досягнення свого народу, своєї Батьківщини, бажання збереження іiі характерних особливостей, iї культурного надбання та захист інтересів своєї громади, народу в цілому. Питанню патріотизму приділено значну увагу на сторінках видання і зокрема досліджено трансформацію цього поняття у свідомості українців.

2) Відродження та розвиток опозиційності. Тижневик відродив i продовжує розвивати в свідомості читачів опозиційні настрої, прагнення жити у цивілізованому суспільстві та пишатися своєю країною, іiі історією та культурою. Одними із варіантів відродження та розвитку опозиційних настроїв $\epsilon$ подання в приклад «Дзеркалом тижня. Україна» розповідей про історичних персонажів, які свого часу не побоялись виступити проти режиму. А також подання інтерв'ю із відомими сучасними культурними діячами, в яких головні герої висловлюють власні опозиційні настрої. При цьому історичні постаті і відомі сучасники виконують роль лідерів думок.

3) Сповідування толерантності та виваженості. При поданні матеріалів історико-культурної проблематики автори «Дзеркала тижня. Україна» не йдуть на провокації, крайнощі та радикалізм, а також спонукають до цього читача.

4) Інтелігентна подача матеріалів. Для інформаційно-аналітичного тижневика «Дзеркало тижня. Україна» характерною є його суттєва, якісна, інтелектуальна складова. Тут відсутні вульгарність, літаючі тарілки, диво-цілителі, гороскопи, чорнуха, екстрасенси та інша «масова культура» бульварних газет і журналів.

5) Спонукання до мудрості, аналізу, міркувань. Своїм головним завданням «Дзеркало тижня» і його автори завжди вважали пошук оптимальних варіантів лікування системи. Автори тижневика завжди намагаються писати без неправди, працювати без халтури, займатися культурною політикою без істерик.

6) «Дзеркало тижня. Україна» популяризує на своїх шпальтах глибоку національну самосвідомість і водночас велику повагу до представників різних національностей, культур, віросповідань. 
Історико-культурних контент тижневика справді $є$ серйозним, вагомим формотворчим чинником національної свідомості. «Дзеркало тижня. Україна» намагається донести до читачів істинні національні ідеї, патріотичні настрої, виховати почуття взаємоповаги до самих себе і до представників різних культур та віросповідань, прагнення жити у цивілізованій, європейській державі Україні і пишатися власною культурою та історією.

«Дзеркало тижня. Україна»- це одне із найпотужніших якісних видань нашої держави, яке утрималось в часи випробувань, яке не залежно від амплітуд зміни політичної та соціально-економічної ситуації в країні, чітко стоїть на позиціях гуманізму, плюралізму та демократизму. Тижневик сміливо можна назвати демократичним суспільно-політичним виданням, що пробуджує опозиційні настрої та системно, програмно формує національну свідомість українців - на політичному, культурному та історичному рівнях.

\section{Література:}

1. Аналітичний звіт за результатами проведення з ініціативи Британської Ради в Україні “круглого столу” “Чим живе культурна журналістика" [Електронний ресурс]. - Британська Рада, 2010. - Режим доступу: http://www.britishcouncil.org/uk/ukraine-press-room-media-discussion-report-ukr.pdf.

2. Дзеркало тижня. Україна. - 2004-2014. - Режим доступу: https://zn.ua/

3. Здоровега В. Й. Теорія і методика журналістської творчості / В.Здоровега. - Л. : ПАІС, 2000. - 180 с.

4. Кузнєцова Т. В. Транслювання національної культури сучасними 3МI: основні тенденції та перспективи [Електронний ресурс] / Тетяна Василівна Кузнєцова. - Режим доступу: http://archive.nbuv.gov.-ua/ portal/natural/vdpu/Soc_komun/2008_1/12.html.

5. Москаленко А. 3. Теорія журналістики : Навч. посібник / Анатолій Москаленко. - К. : Екс. об., 2002. - 334 с.

6. Семінар культурної критики та репортажу “Культура 3.0" [Електронний ресурс]. - CSM, 2014. - Режим доступу: http://issuu.com/ csmart.org.ua/docs/culture-3.0. 